\title{
Integrative Metabolomics to Identify Molecular Signatures of Responses to Vaccines and Infections
}

\author{
Joann Diray-Arce ${ }^{1,2, *\left(\mathbb{D} \text {, Maria Giulia Conti }{ }^{1,3} \text {, Boryana Petrova }\right.}{ }^{2,4}$, Naama Kanarek ${ }^{2,4}$, \\ Asimenia Angelidou 1,2,5 (D) and Ofer Levy 1,2,6,* \\ 1 Precision Vaccines Program, Division of Infectious Diseases, Boston Children's Hospital, Boston, \\ MA 02115, USA; mariagiulia.conti@uniroma1.it (M.G.C.); asimenia.angelidou@childrens.harvard.edu (A.A.) \\ 2 Department of Pediatrics, Harvard Medical School, Boston, MA 02115, USA; \\ boryana.petrova@childrens.harvard.edu (B.P.); naama.kanarek@childrens.harvard.edu (N.K.) \\ 3 Department of Maternal and Child Health, Sapienza University of Rome, 5, 00185 Rome, Italy \\ 4 Department of Pathology, Boston Children's Hospital, Boston, MA 02115, USA \\ 5 Department of Neonatology, Beth Israel Deaconess Medical Center, Boston, MA 02115, USA \\ 6 Broad Institute of MIT \& Harvard, Cambridge, MA 02142, USA \\ * Correspondence: joann.arce@childrens.harvard.edu (J.D.-A.); ofer.levy@childrens.harvard.edu (O.L.)
}

Received: 31 August 2020; Accepted: 30 November 2020; Published: 30 November 2020

\begin{abstract}
Approaches to the identification of metabolites have progressed from early biochemical pathway evaluation to modern high-dimensional metabolomics, a powerful tool to identify and characterize biomarkers of health and disease. In addition to its relevance to classic metabolic diseases, metabolomics has been key to the emergence of immunometabolism, an important area of study, as leukocytes generate and are impacted by key metabolites important to innate and adaptive immunity. Herein, we discuss the metabolomic signatures and pathways perturbed by the activation of the human immune system during infection and vaccination. For example, infection induces changes in lipid (e.g., free fatty acids, sphingolipids, and lysophosphatidylcholines) and amino acid pathways (e.g., tryptophan, serine, and threonine), while vaccination can trigger changes in carbohydrate and bile acid pathways. Amino acid, carbohydrate, lipid, and nucleotide metabolism is relevant to immunity and is perturbed by both infections and vaccinations. Metabolomics holds substantial promise to provide fresh insight into the molecular mechanisms underlying the host immune response. Its integration with other systems biology platforms will enhance studies of human health and disease.
\end{abstract}

Keywords: metabolomics; vaccines; infections; integrative metabolomics; systems biology; diagnosis; response detection

\section{Introduction}

Metabolites are small molecules (50 to 1500 Daltons) produced by regulatory mechanisms and during cellular processes or acquired from exogenous sources, including diet and xenobiotics such as drugs [1]. The metabolic profile provides a snapshot of the complex interplay between genome, environment, and intermediary processes [2]. Metabolites play critical roles in biological pathways and serve as valuable bioindicators of cell physiology [3].

As early as 1955, biochemical research provided the first perspective of a comprehensive cellular metabolome comprised of $\sim 20$ metabolic pathways [4]. As mass spectrometry evolved in the following decades, it dramatically expanded the range and detail of mapping biochemical charts [2]. "Metabolomics" thus emerged as a new frontier in systems biology [5]. Though this technology is powerful and comprehensive, the exact set of metabolites it provides depends on the precise technique employed and its sensitivity and specificity. 
Within the framework of precision medicine and in comparison to other systems biology approaches such as transcriptomics (e.g., RNASeq) and proteomics, metabolomics provides a nearly instantaneous snapshot of metabolism. The metabolome rapidly responds to even minor stimulations, rendering metabolomics a powerful approach to assess quantitative responses to stress [6], nutritional changes [7], disease states [8], host-pathogen interactions [9], as well as short- and long-term metabolic effects of infection [10] and vaccination [11]. The multitude of metabolite changes across space and time and their impact on downstream biological processes produces a complex wealth of data that requires sophisticated detection methods, separation, and analyses based on molecular characteristics. Of note, there are still uncharted areas of the metabolome that may be key to the host response to infection [12-16] and vaccines [17], including the relatively underexamined lipid families assessed via "lipidomics," a branch of metabolomics [18].

This review highlights metabolomics as an emerging tool for identifying signatures and pathways in the host response to infection and vaccination.

\section{Metabolomics-An Emerging Tool to Complement Other Systems Immunology Platforms}

Systems biology approaches that focus on a single class of molecules, such as transcripts (transcriptomics) or proteins (proteomics), can provide important but limited understanding of the biological mechanisms of disease [3]. Their combination with metabolomics provides insights into complementary and synergistic interactions at different cellular and molecular levels [19]. The integration of multi-omic variables addresses gaps in our current knowledge of disease pathogenesis and evolution, offers opportunities for early diagnosis, prevention, and potential treatment of disease, and allows gaining a holistic understanding of a dynamic biological system [20].

Recent systems immunology methodologies have enabled a comprehensive analysis of multiple immune system features in parallel, as well as the identification of cellular and molecular biomarkers not previously known to be relevant to immune responses [21]. Multi-omic integration of metabolomics with other systems biology platforms has enabled the comprehensive characterization of diseases and the identification of metabolic pathways involved in a range of pathologies, including cancer [22-27], chronic obstructive pulmonary disease [28], asthma [29,30], and sepsis [31,32]. The use of systems biology platforms together with metabolomics accelerates biomarker discovery and has been increasingly incorporated in preclinical study workflows such as those related to nutrition and diet [33-38]. Targeted metabolite assays, including those for eicosanoids, arginine, and citrulline, are currently performed for clinical use based on metabolites' association with immune regulatory pathways [39-41] and metabolic diseases [42-44]. In addition, there are existing metabolite tests that are routinely available in the U.S. for point-of-care testing, including those for glucose, 1,5 anhydroglucitol, carbohydrates, lipids, and amino acid (AA) panels to assess glycemic disorders [45].

The potential contribution of metabolomics in the context of infectious diseases and host-pathogen interactions appears particularly promising. Host-pathogen interactions impact leukocyte immunometabolism, thereby shaping their response to infection. Plasm- or serum metabolomics can profile the metabolome in an infected patient, reflecting the systemic responses of diverse cell types in various organ systems affected by a specific pathogen and thereby identifying potential biomarkers of infection [46]. Finally, metabolomics can complement the characterization of complex systems measurements of the effect of a defined immune perturbation such as vaccination (Figure 1). Such an approach is particularly promising in the newborn, given our recent demonstration of marked changes in numerous metabolic pathways across the first week of human life [47], a time of marked susceptibility to infection and of receipt of multiple vaccines, such as via the Expanded Program on Immunization-which includes Bacille Calmette-Guérin vaccine, hepatitis B vaccine, and polio vaccine) $[48,49]$. In light of these proof-of-concept examples, further metabolomic discovery and targeted metabolite validation may provide novel biomarkers of infectious diseases and successful immunization. 

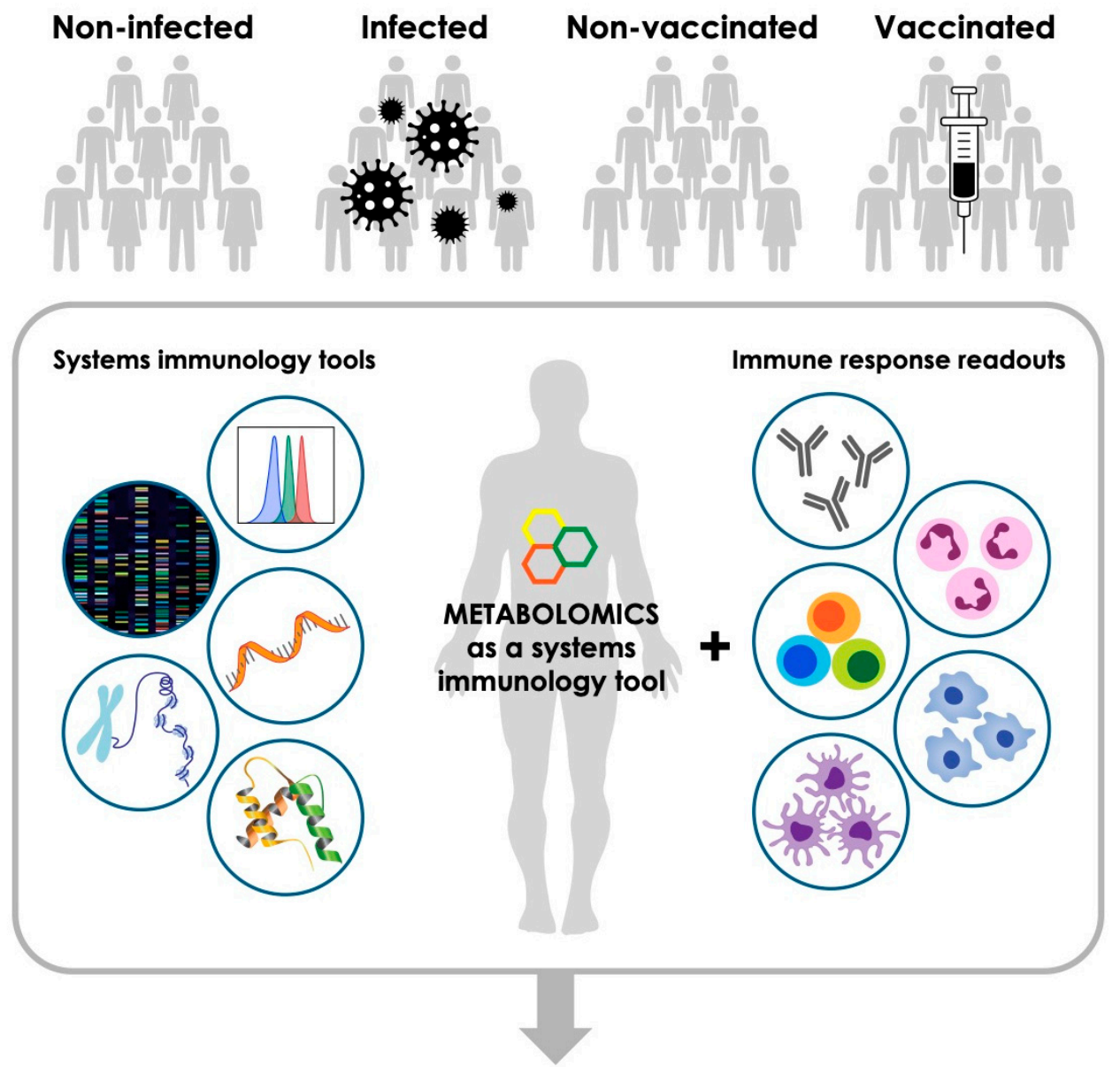

Targeted signatures and pathways

Figure 1. Metabolomics is an emerging tool that can complement other high-throughput systems immunology methods and immune response readouts to identify infection and vaccination biomarkers.

\section{Immunometabolism}

The interplay between metabolism and the immune response is increasingly recognized, and distinct metabolic needs and demands define responses to infection and vaccination [50]. Immunometabolism is a rapidly evolving field of immunology, and the metabolites produced by leukocytes serve as potent immune signaling molecules, during primary (innate), trained (innate memory), and classical adaptive immunity [51]. Trained immunity, the phenomenon of antigen-agnostic memory responses by leukocytes subjected to various environmental threats, is an evolutionary process mediated by epigenetic modulations [52]. Global or targeted metabolomic analysis of pre-defined immune cell populations can lead to novel discoveries of metabolic pathways or molecules that serve as epigenetic or transcriptional regulators. For example, mammalian target of rapamycin (mTOR) signaling, primarily by activating the transcription factor hypoxia-inducible factor- 1 (HIF-1 $\alpha)$, increases aerobic glycolysis and regulates the differentiation of $\mathrm{CD}^{+} \mathrm{T}$ cells, favoring their differentiation into Th17 rather than Treg cells, and the production of pro-inflammatory cytokines in response to $\mathrm{T}$ cell receptor activation [53].

In contrast, adenosine monophosphate-activated protein kinase (AMPK), an energy sensor kinase, serves as an immunometabolic checkpoint in $\mathrm{T}$ cell development and effector responses as well as in memory $\mathrm{T}$ cell differentiation by regulating the metabolic switch from aerobic glycolysis to oxidative phosphorylation of lipids [54]. As is the case for all the body's cells, leukocytes use lipids to synthesize cell membranes and for posttranslational modifications of proteins; therefore, lipid metabolism is relevant to immune responses [55], including those related to epigenetic reprogramming [56]. Integration of metabolomics with other systems biology platforms can enrich 
the discovery, characterization, and validation of immune signatures and networks [47]. Moreover, characterizing the impact of infection and immunization on the immunometabolism of leukocyte populations may inform the discovery and development of target-based therapeutics and vaccines.

\section{Impact of Infection on Host Metabolic Signatures}

During infection, several metabolic changes occur, with reciprocal effects between the pathogen and the host. Metabolic adaptations occurring in eukaryotic hosts upon acute infection by bacterial or viral pathogens are complex, as the pathogen competes for host nutrients and other metabolites to satisfy its bioenergetic and biosynthetic requirements. In contrast, the host response is aimed at the elimination of the invading pathogen [57]. Most microbes enhance specific anabolic pathways in the host and are highly dependent on these alterations, such that the characterization of these metabolic alterations may inform diagnostic, prognostic, and therapeutic applications [58]. Select studies investigating metabolic signatures of infection in the human host are listed in Table 1.

Table 1. Metabolomics identifies biomarkers of human infections. Metabolites noted in more than one infection are in bold. HIV, human immunodeficiency virus, SARS-CoV-2, severe acute respiratory syndrome coronavirus 2, Covid19, coronavirus disease 2019, CSF, cerebrospinal fluid.

\begin{tabular}{|c|c|c|c|c|c|}
\hline $\begin{array}{l}\text { Pathogen } \\
\text { Type Target }\end{array}$ & $\begin{array}{l}\text { Pathogen } \\
\text { (Infection) }\end{array}$ & $\begin{array}{c}\text { Biosample } \\
\text { Type }\end{array}$ & $\begin{array}{l}\text { Technique } \\
\text { Used }\end{array}$ & $\begin{array}{c}\text { Examples of Metabolites or } \\
\text { Metabolic Pathways Perturbed }\end{array}$ & References \\
\hline Bacteria & $\begin{array}{l}\text { Clostridioides } \\
\text { difficile } \\
\text { (infection) }\end{array}$ & stool & $\begin{array}{l}\text { LC-MS, } \\
\text { GC-MS }\end{array}$ & $\begin{array}{l}\text { 2-hydroxy-4-methypentanoic acid, } \\
\text { 2TMS derivative, } \\
\text { 4-methylpentanoic acid, } \\
\text { allo-isoleucine, bile acids, } \\
\text { chenodeoxycholic acid, cholenic } \\
\text { acids, choleonoic acid, } \\
\text { eicosatrienoic acid, fatty acids, } \\
\text { fructose, glyceryl glycoside, } \\
\text { isoleucine, } \\
\text { lysophosphatidylcholine (16:0), } \\
\text { phenylalanine, propylene glycol, } \\
\text { ribitol, sphingolipid, } \\
\text { sphingomyelin, tyrosine, tyrosol }\end{array}$ & {$[59,60]$} \\
\hline Bacteria & $\begin{array}{l}\text { Escherichia coli } \\
\text { (associated } \\
\text { urinary tract } \\
\text { infection) }\end{array}$ & urine & $\begin{array}{l}\text { H-NMR, } \\
\text { LC-MS }\end{array}$ & $\begin{array}{c}\text { acetate, amines, aspartic acid, } \\
\text { cadaverine, citrate, glutamic acid, } \\
\text { glycine, hippurate, } \\
\text { trimethylamine, trimethylamine } \\
\text { n-oxide }\end{array}$ & {$[61,62]$} \\
\hline Bacteria & $\begin{array}{c}\text { Mycobacterium } \\
\text { tuberculosis } \\
\text { (tuberculosis) }\end{array}$ & $\begin{array}{l}\text { plasma, } \\
\text { serum }\end{array}$ & $\begin{array}{l}\text { LC-MS, } \\
\text { FIA-MS, } \\
\text { GC-MS }\end{array}$ & $\begin{array}{c}\text { amino-acyl tRNA, asparagine, } \\
\text { aspartate, citrulline, cysteine, } \\
\text { gamma-glutamylglutamine, fatty } \\
\text { acid metabolism, glutamate, } \\
\text { glutamine, histidine, inosine, } \\
\text { kynurenine, } \\
\text { lysophosphatidylcholines, } \\
\text { medium chain fatty acid, } \\
\text { lysosome pathway, mannose } \\
\text { methionine, protein digestion } \\
\text { pathway, sphingolipid, } \\
\text { sphingosine-1-phosphate, } \\
\text { sulfoxymethionine, tryptophan, } \\
\text { urea }\end{array}$ & {$[13,63-75]$} \\
\hline Virus & $\begin{array}{l}\text { Alphavirus } \\
\text { (Chikungunya) }\end{array}$ & serum & H-NMR & $\begin{array}{l}\text { 2-hydroxycaproic acid, azelaic } \\
\text { acid, carnitine, d-maltose, ethanol, } \\
\text { galactitol, galactose metabolism } \\
\text { and citrate cycle, gluconolactone, } \\
\text { glycine, mandelic acid, } \\
\text { methylguanidine, serine, } \\
\text { threonine metabolism }\end{array}$ & [76] \\
\hline
\end{tabular}


Table 1. Conts.

\begin{tabular}{|c|c|c|c|c|c|}
\hline $\begin{array}{l}\text { Pathogen } \\
\text { Type Target }\end{array}$ & $\begin{array}{l}\text { Pathogen } \\
\text { (Infection) }\end{array}$ & $\begin{array}{c}\text { Biosample } \\
\text { Type }\end{array}$ & $\begin{array}{l}\text { Technique } \\
\text { Used }\end{array}$ & $\begin{array}{c}\text { Examples of Metabolites or } \\
\text { Metabolic Pathways Perturbed }\end{array}$ & References \\
\hline Virus & $\begin{array}{l}\text { Flavivirus } \\
\text { (Dengue) }\end{array}$ & serum & $\begin{array}{l}\text { GC-MS, } \\
\text { LC-MS }\end{array}$ & $\begin{array}{l}\text { acylcarnitines, amino acids, bile } \\
\text { acids, chenodeoxyglycocholic } \\
\text { acid, galactose and pyrimidine, } \\
\text { glycine, glyoxylate and } \\
\text { dicarboxylate, kynurenine, } \\
\text { pentose phosphate pathway, } \\
\text { phospholipids, propanoate, } \\
\text { purines, serine, serotonin, starch } \\
\text { and sucrose, threonine, uric acid }\end{array}$ & [76-79] \\
\hline Virus & $\begin{array}{l}\text { Lentivirus } \\
\text { (human } \\
\text { immunodeficiency } \\
\text { virus/HIV) }\end{array}$ & $\begin{array}{c}\text { CSF, CD4 } 4^{+} \\
\text {T cells, } \\
\text { plasma }\end{array}$ & $\begin{array}{l}\text { H-NMR, } \\
\text { LC-MS, } \\
\text { targeted } \\
\text { LC-MS }\end{array}$ & $\begin{array}{c}\text { acetate, citrate, creatine, } \\
\text { dicarboxylicacylcarnitines, } \\
\text { dopamine, glucose, } \\
\text { glycerophospholipids, glycolysis, } \\
\text { L-aspartate } \\
\text { plasmalogen/plasminogen, } \\
\text { lysophospholipids, } \\
\text { methylglutarylcarnitine, } \\
\text { phosphatidylcholines, } \\
\text { sphingomyelin, } \\
\text { sphingosine-1-phosphate, TCA } \\
\text { cycle }\end{array}$ & [80-83] \\
\hline Virus & $\begin{array}{c}\text { Alphainfluenza } \\
\text { virus } \\
\text { (Influenza) }\end{array}$ & plasma & $\begin{array}{l}\text { H-NMR, } \\
\text { GC-MS }\end{array}$ & $\begin{array}{l}\text { amino acids and ketone bodies, } \\
\text { cAMP, glucose, glutathione, lipid, } \\
\text { N-acetylglucosamine(O-GlcNAc), } \\
\text { purine }\end{array}$ & [84-87] \\
\hline Virus & $\begin{array}{l}\text { SARS-CoV-2 } \\
\text { (COVID19) }\end{array}$ & $\begin{array}{l}\text { plasma, } \\
\text { serum }\end{array}$ & LC-MS & $\begin{array}{c}\text { Bile acids, bile acids, bilirubin, } \\
\text { diacylglycerols, free fatty acid, } \\
\text { glucose, glucuronate, glycerol } \\
\text { 3-phosphate, kynurenine, } \\
\text { lysophosphotidylcholines, malic } \\
\text { acid, } \\
\text { monosialodihexosylganglioside, } \\
\text { phosphatidylcholines, } \\
\text { sphingomyelin, triglycerides, } \\
\text { tryptophan }\end{array}$ & [14,88-92] \\
\hline
\end{tabular}

Common metabolic reactions are essential to host cell defense [93] to prevent microbial access to nutrients [94]. Generic common responses triggered by intracellular bacterial pathogens in host innate immune cells include: (a) induction of host cell reactive oxygen species (ROS) and reactive nitrogen intermediates (RNI) [95,96], (b) enhancement of glucose uptake, which stimulates host cells' anabolic activity $[58,97,98]$, (c) a switch to enhanced glutaminolysis and the citrate lyase reaction [99,100], enhancing fatty acid/lipid biosynthesis, and (d) an overall increase in lipid metabolism, especially the biosynthesis of steroids and eicosanoids [101].

Mycobacterium tuberculosis (Mtb), the causative agent of tuberculosis (TB), is an example of the metabolic adaptation of a bacterium to the host environment, as this pathogen has learned to survive in the host causing a latent infection (LTB) which can progress to active TB disease in $\sim 10 \%$ of latently infected individuals. Carbon metabolism is a major determinant of the pathogenicity of Mtb, as demonstrated in animal models, where the lack of carbon sources causes failed replication and survival. It is essential to fuel Mtb growth [102]. Untargeted metabolite profiling of Mtb growing on ${ }^{13} \mathrm{C}$-labeled carbon substrates revealed that $\mathrm{Mtb}$ could simultaneously catabolize multiple carbon sources (e.g., dextrose, acetate, and glycerol) to augment its growth [64]. The sphingolipid metabolic pathway is another established mediator of the host response to TB [75]. Sphingolipids are fundamental building blocks for cell membranes, are important to immune signaling, and are major constituents of the mucus secreted by lung alveolar epithelial cells [13]. Metabolic signature identification in pulmonary active $\mathrm{TB}$, employing high-resolution plasma metabolomics (HRM), revealed that 
tryptophan metabolism is highly regulated during TB infection and disease and is characterized by increased catabolism to kynurenine, which occurs in both latent and active TB patients [63]. Increased tryptophan catabolism may enable the survival of Mtb at the site of infection by modulating CD4 ${ }^{+}$ $\mathrm{T}$ cell responses, inducing immune tolerance and bacterial persistence, and could also protect the host from excessive inflammation. Metabolomics can identify immunometabolic pathways associated with TB progression, discriminating active TB from latent TB [71]. Fatty acid metabolic networks are critical in TB progression. Mtb favors fatty acids as a cellular nutrient source and the expression of multiple genes dedicated to fatty acid metabolism, at higher levels than those induced by any other microorganism [72,73]. Of note, higher serum concentrations of glutamate, sulfoxy-methionine, and aspartate and lower serum levels of glutamine, methionine, and asparagine are noted in active TB patients compared to latent TB subjects or healthy controls [65]. Lastly, the amino-acyl tRNA pathway is associated with the progression of TB infection to disease, with progressors demonstrating a significant decrease of AA levels compared to controls [71].

Viruses depend on the host cell to obtain macromolecules and on host biosynthesis machinery to replicate; they utilize host cell metabolism according to their specific needs [103]. Viral reprogramming of host metabolism contributes to viral pathogenesis by fueling viral proliferation and survival, enhancing access to free AA, fatty acids, and host-derived lipid membranes, eventually augmenting intercellular signaling promoting evasion of the host's immune system [104]. Some of the significant cellular metabolic pathways, including glycolysis, fatty acid synthesis, and glutaminolysis, are significantly altered by multiple virus families such as HCMV, HCV, HSV-1 poliovirus [103]. Serum metabolomics of chikungunya and/or dengue (co)infection revealed that glycine, serine, threonine, galactose, and pyrimidine metabolism are the most perturbed host pathways in both single and co-infection conditions [76]. Tryptophan metabolites serotonin and kynurenine are differently enriched in patients with dengue hemorrhagic fever (DHF) and their presence may be used in combination with the levels of interferon (IFN)- $\gamma$ for early prognostication of DHF [78]. Analysis of influenza A virus (IAV)-infected cells revealed alterations in several metabolites of the purine, lipid, and glutathione pathways, resulting in the acceleration of viral replication [16].

Retroviruses directly alter host cell metabolism as well. Metabolites involved in glycolysis were increased in human immunodeficiency virus (HIV)-infected CD4 ${ }^{+} \mathrm{T}$ cells [81] but decreased in infected macrophages [82]. Macrophages generally maintain long-term infection, while $\mathrm{CD}^{+} \mathrm{T}$ cells most often are effectors of the acute lytic infection, which may explain the differences. HIV metabonomic studies utilizing biofluids from HIV-infected patients and controls have been used to identify HIV infection biosignatures, disease progression, and immunological responses to treatment [105]. Plasma metabolomics demonstrated deficient concentrations of sphingomyelins and dopamine, in parallel with high levels of dicarboxylicacylcarnitines, L-aspartate, and many plasmalogen/plasminogen phosphatidylcholines in the blood of HIV-1-infected individuals compared with controls [83]. Of note, patients defined as immunological non-responders, demonstrated a downregulation of $\beta$-oxidation, important in $\mathrm{T}$ cell survival, and sphingosine-1-phosphate-phosphatase-1 activity, which is involved in lymphocyte egress from lymphoid organs and the bone marrow. In contrast, acyl-alkyl-containing phosphatidylcholines and alkylglyceronephosphate synthase levels were elevated [83], suggesting that metabolomics can predict a potential rapid disease progression or inadequate antiretroviral immunological responses.

Interestingly, the interaction between glucose metabolism and the inflammatory cytokine network might trigger the host's systemic inflammatory response. Metabolomics of peripheral blood mononuclear cells (PBMCs) challenged with IAV or H1N1 demonstrated that an increase in glucose metabolism promotes viral replication and cytokine production [86]. Plasma metabolomics of study participants with H1N1 influenza A pneumonia or bacterial community-acquired pneumonia (CAP) demonstrated metabolic changes linked to H1N1 pneumonia compared with CAP, including decreased in citrate, fumarate, alanine, and tyrosine levels and increased carnitine, glycine, and acetoacetate levels [85]. 
In the context of the severe acute respiratory syndrome coronavirus-2 (SARS-CoV-2) pandemic, advances in metabolomics can shed light on the pathogenesis of coronavirus disease 2019 (COVID-19) that could inform the development of novel therapeutics. Patients with COVID-19 exhibit changes in serum tryptophan metabolism and increased circulating levels of glucose and free fatty acids (FFA), consistent with altered carbon homeostasis, compared with SARS-CoV-2-negative controls. Interestingly, these findings correlate with the detection of clinical laboratory markers of inflammation (interleukin-6 (IL-6) and C-reactive protein) and renal function (i.e., blood urea nitrogen) [89]. Plasma lipid alterations (i.e., enhanced levels of sphingomyelins (SMs) and monosialodihexosylgangliosides (GM3s) and reduced diacylglycerols (DAGs) associated with COVID-19, detected by targeted and untargeted tandem mass spectrometry analysis of the plasma lipidome and metabolome in mild, moderate, and severe COVID-19 patients and unaffected controls, suggest that SARS-CoV-2 might take advantage of host-derived lipid membranes [90], as it has been described for other coronaviruses [91]. Metabolic signatures may allow the early detection of infected patients at risk for severe disease before the appearance of severe clinical manifestations. Proteomic and metabolomic profiling of sera from COVID-19 and control individuals demonstrated that the elevation of glucose, glucuronate, bilirubin degradation products, and four bile acid derivatives potentially indicates compromised liver detoxification function in patients with severe COVID-19 disease [14]. Plasma metabolite and lipid alterations are more extensive in fatal COVID-19 cases than in patients with severe and mild symptoms [92]. Compared to healthy volunteers, the carbohydrate pathway metabolites malic acid and glycerol 3-phosphate are diminished in symptomatic patients and demonstrated the most significant reduction in patients who died. Plasma lipidomic alterations relate to clinical symptoms of COVID-19: diglyceride (DG), FFA, and triglyceride (TG) concentrations increase with disease deterioration, while concentrations of phosphatidylcholines (PCs) decrease in patients with fatal COVID-19 [92].

\section{Metabolic Signatures of Vaccine-Induced Responses}

Systems vaccinology provides fresh insights into distinct age- and sex-specific vaccine-induced responses [106-109]. The application of metabolomics to vaccinology may identify metabolites that correlate with immunogenicity and inform the tailoring of vaccine regimens for distinct vulnerable populations [109]. Plasma metabolic components, including small molecules and lipids, have immunomodulatory effects that may impact vaccine immunogenicity and infection responses.

Systems vaccinology studies have uncovered metabolic pathways that correlate with vaccine immunogenicity and may have critical roles in immune response mechanisms [11,110,111] (Table 2). Metabolomic studies of influenza immunization of antibiotic-treated study participants demonstrated significant cofactor-/vitamin-related metabolism changes at Day 7 postvaccination compared to baseline [110]. Similarly, dysbiosis associated with bile acid metabolism occurred with antibiotic administration after influenza vaccines, and the IgG1 response was related to metabolic clusters of fatty acid metabolism. These observations suggest that perturbations of the microbiome may impact the levels of critical metabolites, thereby altering the immune response to vaccination [110].

A plasma metabolomic analysis of immune responses to herpes zoster (shingles) Zostavax vaccine demonstrated a strong association of transcriptomic pathways with multiple metabolic pathways, including lipid (e.g., glycerophospholipid, glycosphingolipid, and linoleate metabolism) and AA pathways (methionine and cysteine) at Day 3 postvaccination [11]. These metabolic pathways are also strongly associated with genes related to the MHC-TLR7-TLR8 cluster, antigen presentation, dendritic cell (DC) activation, and B cell signatures [11]. Purine and lysine metabolism were also found to overlap with transcriptomics data at Day 1 versus Day 0. While there was no association between transcriptomics and metabolomics at Day 7 postvaccination, the kinetics of vaccine-induced metabolic shifts may be dependent on gene expression [11].

In a phase III multicenter clinical trial, the Hantavax vaccination (Hantavirus vaccine) demonstrated dose-dependent upregulation of folate biosynthesis, nicotinate, nicotinamide, and arachidonic 
acid metabolism, thiamine levels, and pyrimidine metabolism in the high responder vaccine group [111]. In light of the known roles of metabolic pathways in immunity, Hantavax-induced perturbation of metabolites was thought to be related to immune function, including (a) folate biosynthesis with activation of cell-mediated immunity [112], (b) arachidonic acid metabolism with immune regulation [113], (c) thiamine elevation with enrichment of $\mathrm{T}$ cell differentiation and phagocytosis pathways [114], and (d) pyrimidine metabolism with cell-mediated immunity, T cell activation, and ultimately defeat of the microbial infection [115]. Metabolomics also identified elevation of key metabolites correlating with antibody responses, such as arginine, phenylalanine, cholesteryl nitrolinoleate, and octanoylcarnitine, in the high responder group. Elevated cholesteryl nitrolinoleate in high responders may reflect increased expression of inducible nitric oxide synthase (iNOS), as macrophage activation (e.g., by lipopolysaccharide and INF- $\gamma$ ) can increase the production of this metabolite [116]. Arginine and phenylalanine enhance macrophage activation for enhanced synthesis of nitric oxide (NO) and are key to the antiviral response against herpes simplex virus [117]. Such systems vaccinology studies have identified metabolic pathways that may be important to vaccine immunogenicity and may ultimately inform future vaccine design.

Table 2. Metabolomic studies of human vaccine responses. Metabolites induced by more than one vaccine are in bold. TCA, tricarboxylic acid.

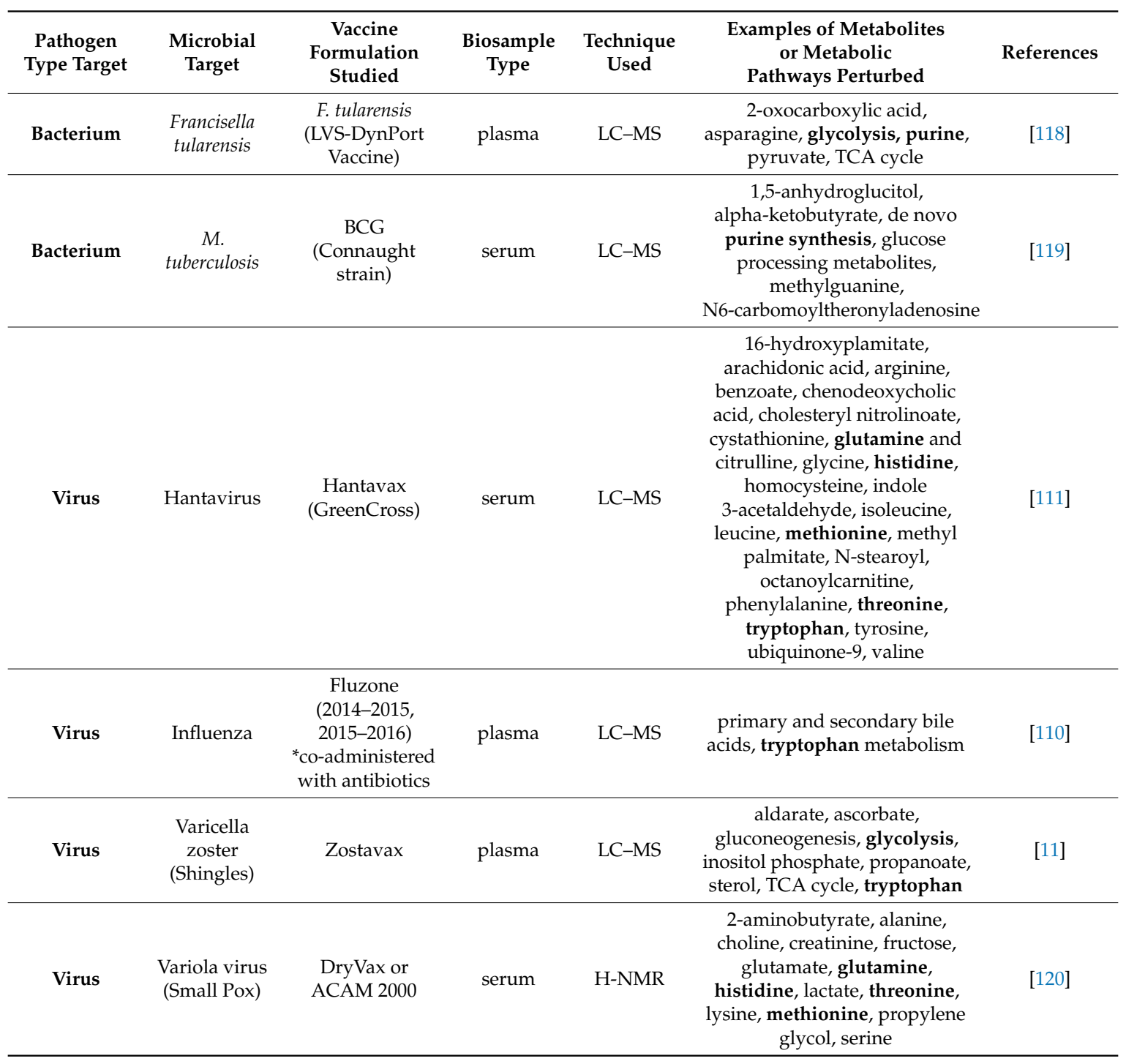


Metabolomics is also being applied to study vaccine safety. A human plasma metabolomics study of 200 individuals pre- and post-small pox immunization discovered novel biomarkers for an adverse event following immunization (AEFI), including redness at the local site of vaccination or a severe allergic reaction [121]. Individuals who experienced clinically verified myocarditis or asymptomatic elevation of troponins were metabolically distinct from controls or those who only experienced systemic symptoms. Creatinine, fructose, phenylalanine, histidine, and serine metabolites were decreased in those with an identified adverse event, suggesting that certain vaccine adverse events may be metabolically mediated [121]. Metabolomics, coupled with machine learning approaches, may predict vaccines' effects and potentially help avoid serious adverse events following immunization, thereby improving the risk/benefit ratio of immunization. In the race for a SARS-CoV-2 vaccine, metabolomic approaches may help identify vaccine candidates that demonstrate relatively low reactogenicity and superior protection. Leveraging systems biology approaches, including metabolomics, may further enhance the benefit-to-risk ratios and the quality of immunization programs, a topic of critical importance in an era of growing vaccine hesitancy.

\section{Shared Metabolic Pathways Across Infection and Vaccination Studies}

Common metabolic pathways induced by infection and vaccination include AA (asparagine, glycine, methionine, threonine, tryptophan, glutamate, glutamine, and serine), carbohydrate (tricarboxylic acid (TCA) cycle, glycolysis, glucose, propanoate), nucleotide (purine), and lipid metabolism (bile acids). Remarkably, these are metabolic pathways known to shape the immune cell response [56,122].

Numerous reviews indicated that AA metabolism shapes the host's physiology, growth, reproduction, and immunity. AA metabolites also serve as the energy source for cells and as regulators for cell signaling and host metabolism $[123,124]$. AA metabolites arginine, asparagine, and tryptophan are identified as central points of competition between the host and the pathogen [125]. Glutamine mediates the activation of Th1 and Th17 cells [126,127] and has also been implicated as an immunomodulatory nutrient that may represent a therapeutic target during severe infection [128]. Serine is required for optimal T cell expansion to support $\mathrm{T}$ cell activation and effector functions and supports de novo purine biosynthesis in proliferating T cells [101,129].

Immunometabolism involving carbohydrate pathways proposes that innate or adaptive naïve immune cells mainly rely on shifting oxidative phosphorylation to glycolysis (Warburg metabolism) upon immune activation [98]. Carbohydrate metabolism pathways are essential host factors influencing responses to bacterial and viral infections [130]. TCA cycle regulation demonstrates a mechanism of host defense against intracellular pathogens through hypoxia and impairment of STAT3 to reduce microbial replication [131]. These carbohydrate metabolic pathways have been extensively shown to promote innate immune cell survival, growth, and physiology [51], provide antimicrobial defense, and prevent hyperinflammatory responses $[132,133]$. Understanding this pathway during host-pathogen interaction is crucial, as each pathogen induces a specific metabolic program, suggesting that research directed at developing species-specific strategies to counter these infections will be fruitful [98].

Purine metabolites provide the necessary energy and cofactors to promote cell survival and proliferation [134]. Adenosine suppresses the proinflammatory response and promotes an anti-inflammatory response through purinergic receptors [135]. Deficiency or mutation of adenosine deaminase activity, a key enzyme for purine metabolite degradation, leads to the accumulation of adenosine, which increases the susceptibility to infection and autoimmunity [136,137]. Bile acids that primarily function in lipid metabolism play key roles in controlling the microbiota composition in the gut [138]. An altered bile acid pool has been associated with infection, suggesting a mechanistic link between the gut microbiota and metabolic syndromes. The interplay between host and pathogen in the gut microbial community underscores the critical involvement of this pathway, as described in vaccination $[11,110,139]$ and infection studies $[138,140]$. 


\section{Integrative Metabolomics-Challenges and Emerging Horizons}

The application of metabolomics for precision medicine is dependent on our ability to categorize infectious disease states or vaccine immunogenicity based on reproducible metabolic signatures that reflect specific, discernible phenotypes and can be used as a consistent readout [141]. For all its many strengths, metabolomics is lagging behind other systems biology fields concerning the standardization of protocols [44] and the routine usage of repositories for mass spectrometry data [142]. Close coordination between researchers, clinicians, and biomedical centers will be necessary to identify reproducible and generalizable metabolic signatures and realize the potential of metabolomics.

Potential obstacles to the broader application of metabolomics for precision medicine have been the prohibitive cost of clinical metabolite profiling and the time-consuming nature of extraction and derivatization of certain metabolites. The typical cost of metabolomics at this time is hundreds of dollars per sample, such that the broad application of global metabolomics is unaffordable, limiting metabolomics-based applications to well-funded clinical trials and perhaps the most privileged patients. To overcome this limitation, technologies such as NMR, which is more affordable than mass spectrometry [143], could be employed, acknowledging the limitations in their detection abilities. Alternatively, detecting a single metabolite or a small group of well-characterized metabolites that were found to be informative of a patient's clinical state can be performed using less costly techniques such as conventional HPLC. Fortunately, current efforts to reduce the cost of mass spectrometry-based methods by several companies might significantly reduce the metabolite profiling costs in the coming years.

At present, the US Food and Drug Administration (FDA) regulations allow the application of metabolomics as a diagnostic tool for in vivo newborn screening of metabolic diseases [144] and for the in vitro identification of bacteria and fungi in clinical samples [145]. Although the FDA has recognized the potential of metabolomics as a promising technology for diagnostics as far back as 2008 [146] and acknowledged its importance and broad applicability to research and development, it has not approved the clinical application of metabolomics for precision medicine. Specific assays of diagnostic markers will have to be individually approved to ensure clinical readouts' safety and accuracy.

As the metabolomics research community finds ways to overcome the current limitations of this powerful technology, the way for personalized metabolic phenotyping will be paved [147,148], which may enable early diagnosis [149], informed treatment choices [150], and accurate prediction of response to therapy [151]. Of note, metabolomics data have advantages compared to data from other screening methods, as they directly measure drug metabolism, inflammation markers, and other ever-changing indicators of a patient's disease status. Such metabolomics data are most useful when integrated with high-quality clinical data (such as ethnicity, age, sex, clinical history, etc.) and molecular data (genomic, transcriptomic, and proteomic data) to inform a comprehensive report of a patient's health status.

Finally, robust structures and incentives for data sharing will be critical to the metabolomics field's success. Extensive studies by investigators in the areas of infectious diseases, vaccinology, and metabolomics, coupled with data sharing, such as that fostered by the Human Immunology Project Consortium ImmPort database [152,153] (www.immport.org), will enable the discovery and validation of cellular and molecular signatures of infection and immunization. Eventually, when integrated with clinical information and validated in clinical contexts, such knowledge may help leveraging metabolic signatures to enhance the diagnosis and treatment of infectious diseases and inform vaccine discovery and development. Given the power of metabolomics and the growing evidence that metabolic pathways are relevant to immune responses, we predict that collaborative data verification and integration efforts will eventually enable the use of metabolic signatures to inform clinical decision-making.

\section{Conclusions}

As the field of metabolomics evolves in accessibility, usability, and sophistication, metabolomic data will increasingly be integrated with clinical and other systems biology data to gain deep insights into the biology of health and disease. On addition to presenting metabolic pathways triggered by infections and vaccinations, our review also highlights metabolomics as a useful tool for discovering 
and identifying biomarkers of disease subtype and stage and treatment response. These biomarkers can be used to distinguish patients infected with different pathogens, predict vaccine-induced protection against these infections, and provide insight into human immunity. Given the emerging evidence that metabolism plays key roles in infection and vaccine responses, a growing number of metabolites will likely emerge as targets for developing biomarkers, predictive algorithms, therapeutic targets, and preventative modalities.

Author Contributions: Conceptualization, J.D.-A.; Writing-Original Draft Preparation, J.D.-A., M.G.C., B.P., N.K., A.A., O.L.; Writing-Review \& Editing, J.D.-A., M.G.C., B.P., N.K., A.A., O.L. All authors have read and agreed to the published version of the manuscript.

Funding: This study was supported by the National Institute of Health/National Institute of Allergy \& Infectious Diseases Human Immunology Project Consortium Grant U19AI118608 and funds from the BCH Precision Vaccines Program.

Acknowledgments: We thank Kristin Johnson for illustration and Diana Vo for programmatic support.

Conflicts of Interest: Ofer Levy is a named inventor on several Boston Children's Hospital patent applications relating to human in vitro assays systems and vaccine adjuvants. The other authors declare no competing financial interests.

\section{References}

1. Viant, M.R.; Kurland, I.J.; Jones, M.R.; Dunn, W.B. How close are we to complete annotation of metabolomes? Curr. Opin. Chem. Biol. 2017, 36, 64-69. [CrossRef] [PubMed]

2. Johnson, C.H.; Ivanisevic, J.; Siuzdak, G. Metabolomics: Beyond biomarkers and towards mechanisms. Nat. Rev. Mol. Cell Biol. 2016, 17, 451-459. [CrossRef] [PubMed]

3. Sun, Y.V.; Hu, Y.J. Integrative Analysis of Multi-omics Data for Discovery and Functional Studies of Complex Human Diseases. Adv. Genet. 2016, 93, 147-190. [CrossRef] [PubMed]

4. Atkinson, D.E. An Introduction to Metabolic Pathways. S. Dagley, Donald E. Nicholson. Q. Rev. Biol. 1971, 46, 288-290. [CrossRef]

5. Veenstra, T.D. Metabolomics: The final frontier? Genome Med. 2012, 4, 40. [CrossRef] [PubMed]

6. Yuan, H.; Xu, Y.; Chen, Y.; Zhan, Y.; Wei, X.; Li, L.; Wang, D.; He, P.; Li, S.; Chen, S. Metabolomics analysis reveals global acetoin stress response of Bacillus licheniformis. Metabolomics 2019, 15, 25. [CrossRef] [PubMed]

7. Blighe, K.; Chawes, B.L.; Kelly, R.S.; Mirzakhani, H.; McGeachie, M.; Litonjua, A.A.; Weiss, S.T.; Lasky-Su, J.A. Vitamin D prenatal programming of childhood metabolomics profiles at age 3 y. Am. J. Clin. Nutr. 2017, 106, 1092-1099. [CrossRef] [PubMed]

8. Sun, C.; Li, T.; Song, X.; Huang, L.; Zang, Q.; Xu, J.; Bi, N.; Jiao, G.; Hao, Y.; Chen, Y.; et al. Spatially resolved metabolomics to discover tumor-associated metabolic alterations. Proc. Natl. Acad. Sci. USA 2019, 116, 52-57. [CrossRef]

9. Liu, N.N.; Acosta-Zaldivar, M.; Qi, W.; Diray-Arce, J.; Walker, L.A.; Kottom, T.J.; Kelly, R.; Yuan, M.; Asara, J.M.; Lasky-Su, J.A.; et al. Phosphoric Metabolites Link Phosphate Import and Polysaccharide Biosynthesis for Candida albicans Cell Wall Maintenance. mBio 2020, 11. [CrossRef] [PubMed]

10. Beale, D.J.; Oh, D.Y.; Karpe, A.V.; Tai, C.; Dunn, M.S.; Tilmanis, D.; Palombo, E.A.; Hurt, A.C. Untargeted metabolomics analysis of the upper respiratory tract of ferrets following influenza A virus infection and oseltamivir treatment. Metabolomics 2019, 15, 33. [CrossRef] [PubMed]

11. Li, S.; Sullivan, N.L.; Rouphael, N.; Yu, T.; Banton, S.; Maddur, M.S.; McCausland, M.; Chiu, C.; Canniff, J.; Dubey, S.; et al. Metabolic Phenotypes of Response to Vaccination in Humans. Cell 2017, 169, 862-877. [CrossRef] [PubMed]

12. Abu-Farha, M.; Thanaraj, T.A.; Qaddoumi, M.G.; Hashem, A.; Abubaker, J.; Al-Mulla, F. The Role of Lipid Metabolism in COVID-19 Virus Infection and as a Drug Target. Int. J. Mol. Sci. 2020, 21, 3544. [CrossRef] [PubMed]

13. Sharma, L.; Prakash, H. Sphingolipids Are Dual Specific Drug Targets for the Management of Pulmonary Infections: Perspective. Front. Immunol. 2017, 8, 378. [CrossRef] [PubMed]

14. Shen, B.; Yi, X.; Sun, Y.; Bi, X.; Du, J.; Zhang, C.; Quan, S.; Zhang, F.; Sun, R.; Qian, L.; et al. Proteomic and Metabolomic Characterization of COVID-19 Patient Sera. Cell 2020, 182, 59-72. [CrossRef] [PubMed]

15. Smith, C.L.; Dickinson, P.; Forster, T.; Craigon, M.; Ross, A.; Khondoker, M.R.; France, R.; Ivens, A.; Lynn, D.J.; Orme, J.; et al. Identification of a human neonatal immune-metabolic network associated with bacterial infection. Nat. Commun. 2014, 5, 4649. [CrossRef] [PubMed] 
16. Tian, X.; Zhang, K.; Min, J.; Chen, C.; Cao, Y.; Ding, C.; Liu, W.; Li, J. Metabolomic Analysis of Influenza A Virus A/WSN/1933 (H1N1) Infected A549 Cells during First Cycle of Viral Replication. Viruses 2019, 11, 1007. [CrossRef] [PubMed]

17. Niki, M.; Yoshiyama, T.; Nagai, H.; Miyamoto, Y.; Niki, M.; Oinuma, K.I.; Tsubouchi, T.; Kaneko, Y.; Matsumoto, S.; Sasaki, Y.; et al. Nutritional status positively impacts humoral immunity against its Mycobacterium tuberculosis, disease progression, and vaccine development. PLOS ONE 2020, 15, e0237062. [CrossRef]

18. German, J.B.; Gillies, L.A.; Smilowitz, J.T.; Zivkovic, A.M.; Watkins, S.M. Lipidomics and lipid profiling in metabolomics. Curr. Opin. Lipidol. 2007, 18, 66-71. [CrossRef]

19. Chen, R.; Mias, G.I.; Li-Pook-Than, J.; Jiang, L.; Lam, H.Y.; Chen, R.; Miriami, E.; Karczewski, K.J.; Hariharan, M.; Dewey, F.E.; et al. Personal omics profiling reveals dynamic molecular and medical phenotypes. Cell 2012, 148, 1293-1307. [CrossRef]

20. Petersen, A.K.; Zeilinger, S.; Kastenmuller, G.; Romisch-Margl, W.; Brugger, M.; Peters, A.; Meisinger, C.; Strauch, K.; Hengstenberg, C.; Pagel, P.; et al. Epigenetics meets metabolomics: An epigenome-wide association study with blood serum metabolic traits. Hum. Mol. Genet. 2014, 23, 534-545. [CrossRef]

21. Nakaya, H.I.; Li, S.; Pulendran, B. Systems vaccinology: Learning to compute the behavior of vaccine induced immunity. Wiley Interdiscip. Rev. Syst. Biol. Med. 2012, 4, 193-205. [CrossRef] [PubMed]

22. Ren, S.; Shao, Y.; Zhao, X.; Hong, C.S.; Wang, F.; Lu, X.; Li, J.; Ye, G.; Yan, M.; Zhuang, Z.; et al. Integration of Metabolomics and Transcriptomics Reveals Major Metabolic Pathways and Potential Biomarker Involved in Prostate Cancer. Mol. Cell. Proteom. 2016, 15, 154-163. [CrossRef] [PubMed]

23. Chaudhary, K.; Poirion, O.B.; Lu, L.; Garmire, L.X. Deep Learning-Based Multi-Omics Integration Robustly Predicts Survival in Liver Cancer. Clin. Cancer Res. 2018, 24, 1248-1259. [CrossRef] [PubMed]

24. Hakimi, A.A.; Reznik, E.; Lee, C.H.; Creighton, C.J.; Brannon, A.R.; Luna, A.; Aksoy, B.A.; Liu, E.M.; Shen, R.; Lee, W.; et al. An Integrated Metabolic Atlas of Clear Cell Renal Cell Carcinoma. Cancer Cell 2016, 29, 104-116. [CrossRef] [PubMed]

25. Hsu, C.W.; Chen, Y.T.; Hsieh, Y.J.; Chang, K.P.; Hsueh, P.C.; Chen, T.W.; Yu, J.S.; Chang, Y.S.; Li, L.; Wu, C.C. Integrated analyses utilizing metabolomics and transcriptomics reveal perturbation of the polyamine pathway in oral cavity squamous cell carcinoma. Anal. Chim. Acta 2019, 1050, 113-122. [CrossRef]

26. Zhang, G.; He, P.; Tan, H.; Budhu, A.; Gaedcke, J.; Ghadimi, B.M.; Ried, T.; Yfantis, H.G.; Lee, D.H.; Maitra, A.; et al. Integration of metabolomics and transcriptomics revealed a fatty acid network exerting growth inhibitory effects in human pancreatic cancer. Clin. Cancer Res. 2013, 19, 4983-4993. [CrossRef]

27. Yang, K.; Xia, B.; Wang, W.; Cheng, J.; Yin, M.; Xie, H.; Li, J.; Ma, L.; Yang, C.; Li, A.; et al. A Comprehensive Analysis of Metabolomics and Transcriptomics in Cervical Cancer. Sci. Rep. 2017, 7, 43353. [CrossRef]

28. Ghosh, N.; Dutta, M.; Singh, B.; Banerjee, R.; Bhattacharyya, P.; Chaudhury, K. Transcriptomics, proteomics and metabolomics driven biomarker discovery in COPD: An update. Expert Rev. Mol. Diagn. 2016, 16, 897-913. [CrossRef]

29. Kuruvilla, M.E.; Lee, F.E.; Lee, G.B. Understanding Asthma Phenotypes, Endotypes, and Mechanisms of Disease. Clin. Rev. Allergy Immunol. 2019, 56, 219-233. [CrossRef]

30. Kelly, R.S.; Chawes, B.L.; Blighe, K.; Virkud, Y.V.; Croteau-Chonka, D.C.; McGeachie, M.J.; Clish, C.B.; Bullock, K.; Celedon, J.C.; Weiss, S.T.; et al. An Integrative Transcriptomic and Metabolomic Study of Lung Function in Children With Asthma. Chest 2018, 154, 335-348. [CrossRef]

31. Lee, J.; Banerjee, D. Metabolomics and the Microbiome as Biomarkers in Sepsis. Crit. Care Clin. 2020, 36, 105-113. [CrossRef] [PubMed]

32. Xu, D.; Liao, S.; Li, P.; Zhang, Q.; Lv, Y.; Fu, X.; Yang, M.; Wang, J.; Kong, L. Metabolomics Coupled with Transcriptomics Approach Deciphering Age Relevance in Sepsis. Aging Dis. 2019, 10, 854-870. [CrossRef] [PubMed]

33. Tang, Z.Z.; Chen, G.; Hong, Q.; Huang, S.; Smith, H.M.; Shah, R.D.; Scholz, M.; Ferguson, J.F. Multi-Omic Analysis of the Microbiome and Metabolome in Healthy Subjects Reveals Microbiome-Dependent Relationships Between Diet and Metabolites. Front. Genet. 2019, 10, 454. [CrossRef] [PubMed]

34. Zierer, J.; Jackson, M.A.; Kastenmuller, G.; Mangino, M.; Long, T.; Telenti, A.; Mohney, R.P.; Small, K.S.; Bell, J.T.; Steves, C.J.; et al. The fecal metabolome as a functional readout of the gut microbiome. Nat. Genet. 2018, 50, 790-795. [CrossRef]

35. Wilmanski, T.; Rappaport, N.; Earls, J.C.; Magis, A.T.; Manor, O.; Lovejoy, J.; Omenn, G.S.; Hood, L.; Gibbons, S.M.; Price, N.D. Blood metabolome predicts gut microbiome alpha-diversity in humans. Nat. Biotechnol. 2019, 37, 1217-1228. [CrossRef] [PubMed] 
36. Dao, M.C.; Sokolovska, N.; Brazeilles, R.; Affeldt, S.; Pelloux, V.; Prifti, E.; Chilloux, J.; Verger, E.O.; Kayser, B.D.; Aron-Wisnewsky, J.; et al. A Data Integration Multi-Omics Approach to Study Calorie Restriction-Induced Changes in Insulin Sensitivity. Front. Physiol. 2018, 9, 1958. [CrossRef] [PubMed]

37. Kiebish, M.A.; Cullen, J.; Mishra, P.; Ali, A.; Milliman, E.; Rodrigues, L.O.; Chen, E.Y.; Tolstikov, V.; Zhang, L.; Panagopoulos, K.; et al. Multi-omic serum biomarkers for prognosis of disease progression in prostate cancer. J. Transl. Med. 2020, 18, 10. [CrossRef]

38. Khan, S.R.; Manialawy, Y.; Wheeler, M.B.; Cox, B.J. Unbiased data analytic strategies to improve biomarker discovery in precision medicine. Drug Discov. Today 2019, 24, 1735-1748. [CrossRef]

39. Lone, A.M.; Tasken, K. Proinflammatory and immunoregulatory roles of eicosanoids in T cells. Front. Immunol. 2013, 4, 130. [CrossRef]

40. Yui, K.; Imataka, G.; Nakamura, H.; Ohara, N.; Naito, Y. Eicosanoids Derived From Arachidonic Acid and Their Family Prostaglandins and Cyclooxygenase in Psychiatric Disorders. Curr. Neuropharmacol. 2015, 13, 776-785. [CrossRef]

41. Wijnands, K.A.; Castermans, T.M.; Hommen, M.P.; Meesters, D.M.; Poeze, M. Arginine and citrulline and the immune response in sepsis. Nutrients 2015, 7, 1426-1463. [CrossRef] [PubMed]

42. Nikolaus, S.; Schulte, B.; Al-Massad, N.; Thieme, F.; Schulte, D.M.; Bethge, J.; Rehman, A.; Tran, F.; Aden, K.; Hasler, R.; et al. Increased Tryptophan Metabolism Is Associated With Activity of Inflammatory Bowel Diseases. Gastroenterology 2017, 153, 1504-1516. [CrossRef] [PubMed]

43. Lu, J.Y.; Peng, J.H.; Ma, X.J.; Zhang, Y.N.; Zhu, W.; He, X.X.; Ying, L.W.; Bao, Y.Q.; Zhou, J.; Jia, W.P. Metabolic perturbations of post-load hyperglycemia vs. fasting hyperglycemia. Acta Pharmacol. Sin. 2019, 40, $216-221$. [CrossRef] [PubMed]

44. Long, N.P.; Nghi, T.D.; Kang, Y.P.; Anh, N.H.; Kim, H.M.; Park, S.K.; Kwon, S.W. Toward a Standardized Strategy of Clinical Metabolomics for the Advancement of Precision Medicine. Metabolites 2020, 10, 51. [CrossRef] [PubMed]

45. Bergman, M.; Abdul-Ghani, M.; DeFronzo, R.A.; Manco, M.; Sesti, G.; Fiorentino, T.V.; Ceriello, A.; Rhee, M.; Phillips, L.S.; Chung, S.; et al. Review of methods for detecting glycemic disorders. Diabetes Res. Clin. Pract. 2020, 165, 108233. [CrossRef]

46. Nguyen, C.T.; Shetty, V.; Maresso, A.W. Global metabolomic analysis of a mammalian host infected with Bacillus anthracis. Infect. Immun. 2015, 83, 4811-4825. [CrossRef]

47. Lee, A.H.; Shannon, C.P.; Amenyogbe, N.; Bennike, T.B.; Diray-Arce, J.; Idoko, O.T.; Gill, E.E.; Ben-Othman, R.; Pomat, W.S.; van Haren, S.D.; et al. Dynamic molecular changes during the first week of human life follow a robust developmental trajectory. Nat. Commun. 2019, 10, 1092. [CrossRef]

48. Whittaker, E.; Goldblatt, D.; McIntyre, P.; Levy, O. Neonatal Immunization: Rationale, Current State, and Future Prospects. Front. Immunol. 2018, 9, 532. [CrossRef]

49. Idoko, O.T.; Smolen, K.K.; Wariri, O.; Imam, A.; Shannon, C.P.; Dibassey, T.; Diray-Arce, J.; Darboe, A.; Strandmark, J.; Ben-Othman, R.; et al. Clinical Protocol for a Longitudinal Cohort Study Employing Systems Biol. to Identify Markers of Vaccine Immunogenicity in Newborn Infants in The Gambia and Papua New Guinea. Front. Pediatr. 2020, 8, 197. [CrossRef]

50. Kumar, V. Immunometabolism: Another Road to Sepsis and Its Therapeutic Targeting. Inflammation 2019, 42, 765-788. [CrossRef]

51. Conti, M.G.; Angelidou, A.; Diray-Arce, J.; Smolen, K.K.; Lasky-Su, J.; De Curtis, M.; Levy, O. Immunometabolic approaches to prevent, detect, and treat neonatal sepsis. Pediatr. Res. 2020, 87, 399-405. [CrossRef] [PubMed]

52. Netea, M.G.; Joosten, L.A.; Latz, E.; Mills, K.H.; Natoli, G.; Stunnenberg, H.G.; O’Neill, L.A.; Xavier, R.J. Trained immunity: A program of innate immune memory in health and disease. Science 2016, 352, aaf1098. [CrossRef] [PubMed]

53. Dang, E.V.; Barbi, J.; Yang, H.Y.; Jinasena, D.; Yu, H.; Zheng, Y.; Bordman, Z.; Fu, J.; Kim, Y.; Yen, H.R.; et al. Control of T(H)17/T(reg) balance by hypoxia-inducible factor 1. Cell 2011, 146, 772-784. [CrossRef] [PubMed]

54. Araki, K.; Ahmed, R. AMPK: A metabolic switch for CD8+ T-cell memory. Eur. J. Immunol. 2013, 43, 878-881. [CrossRef]

55. Lochner, M.; Berod, L.; Sparwasser, T. Fatty acid metabolism in the regulation of T cell function. Trends Immunol. 2015, 36, 81-91. [CrossRef]

56. O’Neill, L.A.J.; Kishton, R.J.; Rathmell, J. A guide to immunometabolism for immunologists. Nat. Rev. Immunol. 2016, 16, 553-565. [CrossRef] 
57. Mayer, K.A.; Stöckl, J.; Zlabinger, G.J.; Gualdoni, G.A. Hijacking the Supplies: Metabolism as a Novel Facet of Virus-Host Interaction. Front. Immunol. 2019, 10. [CrossRef]

58. Eisenreich, W.; Rudel, T.; Heesemann, J.; Goebel, W. How Viral and Intracellular Bacterial Pathogens Reprogram the Metabolism of Host Cells to Allow Their Intracellular Replication. Front. Cell. Infect. Microbiol. 2019, 9, 42. [CrossRef]

59. Robinson, J.I.; Weir, W.H.; Crowley, J.R.; Hink, T.; Reske, K.A.; Kwon, J.H.; Burnham, C.D.; Dubberke, E.R.; Mucha, P.J.; Henderson, J.P. Metabolomic networks connect host-microbiome processes to human Clostridioides difficile infections. J. Clin. Investig. 2019, 129, 3792-3806. [CrossRef]

60. Zhou, P.; Zhou, N.; Shao, L.; Li, J.; Liu, S.; Meng, X.; Duan, J.; Xiong, X.; Huang, X.; Chen, Y.; et al. Diagnosis of Clostridium difficile infection using an UPLC-MS based metabolomics method. Metabolomics 2018, 14, 102. [CrossRef]

61. Lussu, M.; Camboni, T.; Piras, C.; Serra, C.; Del Carratore, F.; Griffin, J.; Atzori, L.; Manzin, A. (1)H NMR spectroscopy-based metabolomics analysis for the diagnosis of symptomatic E. coli-associated urinary tract infection (UTI). BMC Microbiol. 2017, 17, 201. [CrossRef] [PubMed]

62. Puebla-Barragan, S.; Renaud, J.; Sumarah, M.; Reid, G. Malodorous biogenic amines in Escherichia coli-caused urinary tract infections in women-a metabolomics approach. Sci. Rep. 2020, 10, 9703. [CrossRef] [PubMed]

63. Collins, J.M.; Siddiqa, A.; Jones, D.P.; Liu, K.; Kempker, R.R.; Nizam, A.; Shah, N.S.; Ismail, N.; Ouma, S.G.; Tukvadze, N.; et al. Tryptophan catabolism reflects disease activity in human tuberculosis. JCI Insight 2020, 5. [CrossRef] [PubMed]

64. De Carvalho, L.P.; Fischer, S.M.; Marrero, J.; Nathan, C.; Ehrt, S.; Rhee, K.Y. Metabolomics of Mycobacterium tuberculosis reveals compartmentalized co-catabolism of carbon substrates. Chem. Biol. 2010, 17, 1122-1131. [CrossRef]

65. Cho, Y.; Park, Y.; Sim, B.; Kim, J.; Lee, H.; Cho, S.-N.; Kang, Y.A.; Lee, S.-G. Identification of serum biomarkers for active pulmonary tuberculosis using a targeted metabolomics approach. Sci. Rep. 2020, 10, 3825. [CrossRef]

66. Frediani, J.K.; Jones, D.P.; Tukvadze, N.; Uppal, K.; Sanikidze, E.; Kipiani, M.; Tran, V.T.; Hebbar, G.; Walker, D.I.; Kempker, R.R.; et al. Plasma metabolomics in human pulmonary tuberculosis disease: A pilot study. PLOS ONE 2014, 9, e108854. [CrossRef]

67. Zhou, A.; Ni, J.; Xu, Z.; Wang, Y.; Lu, S.; Sha, W.; Karakousis, P.C.; Yao, Y.-F. Application of (1)h NMR spectroscopy-based metabolomics to sera of tuberculosis patients. J. Proteome Res. 2013, 12, 4642-4649. [CrossRef]

68. Weiner, J., 3rd; Parida, S.K.; Maertzdorf, J.; Black, G.F.; Repsilber, D.; Telaar, A.; Mohney, R.P.; Arndt-Sullivan, C.; Ganoza, C.A.; Fae, K.C.; et al. Biomarkers of inflammation, immunosuppression and stress with active disease are revealed by metabolomic profiling of tuberculosis patients. PLoS ONE 2012, 7, e40221. [CrossRef]

69. Sun, L.; Li, J.Q.; Ren, N.; Qi, H.; Dong, F.; Xiao, J.; Xu, F.; Jiao, W.W.; Shen, C.; Song, W.Q.; et al. Utility of Novel Plasma Metabolic Markers in the Diagnosis of Pediatric Tuberculosis: A Classification and Regression Tree Analysis Approach. J. Proteome Res. 2016, 15, 3118-3125. [CrossRef]

70. Weiner, J., 3rd; Maertzdorf, J.; Sutherland, J.S.; Duffy, F.J.; Thompson, E.; Suliman, S.; McEwen, G.; Thiel, B.; Parida, S.K.; Zyla, J.; et al. Metabolite changes in blood predict the onset of tuberculosis. Nat. Commun. 2018, 9, 5208. [CrossRef]

71. Duffy, F.J.; Weiner, J., 3rd; Hansen, S.; Tabb, D.L.; Suliman, S.; Thompson, E.; Maertzdorf, J.; Shankar, S.; Tromp, G.; Parida, S.; et al. Immunometabolic Signatures Predict Risk of Progression to Active Tuberculosis and Disease Outcome. Front. Immunol. 2019, 10, 527. [CrossRef] [PubMed]

72. Lee, W.; VanderVen, B.C.; Fahey, R.J.; Russell, D.G. Intracellular Mycobacterium tuberculosis exploits host-derived fatty acids to limit metabolic stress. J. Biol. Chem. 2013, 288, 6788-6800. [CrossRef] [PubMed]

73. Kinsella, R.J.; Fitzpatrick, D.A.; Creevey, C.J.; McInerney, J.O. Fatty acid biosynthesis in Mycobacterium tuberculosis: Lateral gene transfer, adaptive evolution, and gene duplication. Proc. Natl. Acad. Sci. USA 2003, 100, 10320-10325. [CrossRef] [PubMed]

74. MacGurn, J.A.; Cox, J.S. A genetic screen for Mycobacterium tuberculosis mutants defective for phagosome maturation arrest identifies components of the ESX-1 secretion system. Infect. Immun. 2007, 75, 2668-2678. [CrossRef] [PubMed]

75. Garg, S.K.; Volpe, E.; Palmieri, G.; Mattei, M.; Galati, D.; Martino, A.; Piccioni, M.S.; Valente, E.; Bonanno, E.; De Vito, P.; et al. Sphingosine 1-Phosphate Induces Antimicrobial Activity Both In Vitro and In Vivo. J. Infect. Dis. 2004, 189, 2129-2138. [CrossRef] 
76. Shrinet, J.; Shastri, J.S.; Gaind, R.; Bhavesh, N.S.; Sunil, S. Serum metabolomics analysis of patients with chikungunya and dengue mono/co-infections reveals distinct metabolite signatures in the three disease conditions. Sci. Rep. 2016, 6, 36833. [CrossRef]

77. Cui, L.; Lee, Y.H.; Kumar, Y.; Xu, F.; Lu, K.; Ooi, E.E.; Tannenbaum, S.R.; Ong, C.N. Serum metabolome and lipidome changes in adult patients with primary dengue infection. PLoS Negl. Trop. Dis. 2013, 7, e2373. [CrossRef]

78. Cui, L.; Lee, Y.H.; Thein, T.L.; Fang, J.; Pang, J.; Ooi, E.E.; Leo, Y.S.; Ong, C.N.; Tannenbaum, S.R. Serum Metabolomics Reveals Serotonin as a Predictor of Severe Dengue in the Early Phase of Dengue Fever. PLoS Negl. Trop. Dis. 2016, 10, e0004607. [CrossRef]

79. Cui, L.; Pang, J.; Lee, Y.H.; Ooi, E.E.; Ong, C.N.; Leo, Y.S.; Tannenbaum, S.R. Serum metabolome changes in adult patients with severe dengue in the critical and recovery phases of dengue infection. PLoS Negl. Trop. Dis. 2018, 12, e0006217. [CrossRef]

80. Dickens, A.M.; Anthony, D.C.; Deutsch, R.; Mielke, M.M.; Claridge, T.D.; Grant, I.; Franklin, D.; Rosario, D.; Marcotte, T.; Letendre, S.; et al. Cerebrospinal fluid metabolomics implicate bioenergetic adaptation as a neural mechanism regulating shifts in cognitive states of HIV-infected patients. AIDS 2015, 29, 559-569. [CrossRef]

81. Chan, E.Y.; Sutton, J.N.; Jacobs, J.M.; Bondarenko, A.; Smith, R.D.; Katze, M.G. Dynamic host energetics and cytoskeletal proteomes in human immunodeficiency virus type 1-infected human primary CD4 cells: Analysis by multiplexed label-free mass spectrometry. J. Virol. 2009, 83, 9283-9295. [CrossRef]

82. Hollenbaugh, J.A.; Munger, J.; Kim, B. Metabolite profiles of human immunodeficiency virus infected CD4+ T cells and macrophages using LC-MS/MS analysis. Virology 2011, 415, 153-159. [CrossRef] [PubMed]

83. Scarpellini, B.; Zanoni, M.; Sucupira, M.C.; Truong, H.M.; Janini, L.M.; Segurado, I.D.; Diaz, R.S. Plasma Metabolomics Biosignature According to HIV Stage of Infection, Pace of Disease Progression, Viremia Level and Immunological Response to Treatment. PLOS ONE 2016, 11, e0161920. [CrossRef] [PubMed]

84. Serezani, C.H.; Ballinger, M.N.; Aronoff, D.M.; Peters-Golden, M. Cyclic AMP: Master regulator of innate immune cell function. Am. J. Respir. Cell Mol. Biol. 2008, 39, 127-132. [CrossRef] [PubMed]

85. Banoei, M.M.; Vogel, H.J.; Weljie, A.M.; Kumar, A.; Yende, S.; Angus, D.C.; Winston, B.W.; Canadian Critical Care Translational Biology Group. Plasma metabolomics for the diagnosis and prognosis of H1N1 influenza pneumonia. Crit. Care 2017, 21, 97. [CrossRef] [PubMed]

86. Wang, Q.; Fang, P.; He, R.; Li, M.; Yu, H.; Zhou, L.; Yi, Y.; Wang, F.; Rong, Y.; Zhang, Y.; et al. O-GlcNAc transferase promotes influenza A virus-induced cytokine storm by targeting interferon regulatory factor-5. Sci. Adv. 2020, 6, eaaz7086. [CrossRef] [PubMed]

87. Cui, L.; Zheng, D.; Lee, Y.H.; Chan, T.K.; Kumar, Y.; Ho, W.E.; Chen, J.Z.; Tannenbaum, S.R.; Ong, C.N. Metabolomics Investigation Reveals Metabolite Mediators Associated with Acute Lung Injury and Repair in a Murine Model of Influenza Pneumonia. Sci. Rep. 2016, 6, 26076. [CrossRef]

88. Mehta, P.; McAuley, D.F.; Brown, M.; Sanchez, E.; Tattersall, R.S.; Manson, J.J.; Hlh Across Speciality Collaboration, U.K. COVID-19: Consider cytokine storm syndromes and immunosuppression. Lancet 2020, 395, 1033-1034. [CrossRef]

89. Thomas, T.; Stefanoni, D.; Reisz, J.A.; Nemkov, T.; Bertolone, L.; Francis, R.O.; Hudson, K.E.; Zimring, J.C.; Hansen, K.C.; Hod, E.A.; et al. COVID-19 infection alters kynurenine and fatty acid metabolism, correlating with IL-6 levels and renal status. JCI Insight 2020, 5. [CrossRef]

90. Song, J.W.; Lam, S.M.; Fan, X.; Cao, W.J.; Wang, S.Y.; Tian, H.; Chua, G.H.; Zhang, C.; Meng, F.P.; Xu, Z.; et al. Omics-Driven Systems Interrogation of Metabolic Dysregulation in COVID-19 Pathogenesis. Cell Metab. 2020, 32, 188-202.e5. [CrossRef]

91. Hong, W. Combating COVID-19 with Chloroquine. J. Mol. Cell Biol. 2020, 12, 249-250. [CrossRef] [PubMed]

92. Wu, D.; Shu, T.; Yang, X.; Song, J.-X.; Zhang, M.; Yao, C.; Liu, W.; Huang, M.; Yu, Y.; Yang, Q.; et al. Plasma metabolomic and lipidomic alterations associated with COVID-19. Natl. Sci. Rev. 2020, 7, 1157-1168. [CrossRef]

93. Bogdan, C.; Rollinghoff, M.; Diefenbach, A. Reactive oxygen and reactive nitrogen intermediates in innate and specific immunity. Curr. Opin. Immunol. 2000, 12, 64-76. [CrossRef]

94. Appelberg, R. Macrophage nutriprive antimicrobial mechanisms. J. Leukoc. Biol. 2006, 79, 1117-1128. [CrossRef]

95. Spooner, R.; Yilmaz, O. The role of reactive-oxygen-species in microbial persistence and inflammation. Int. J. Mol. Sci. 2011, 12, 334-352. [CrossRef]

96. Nathan, C.; Shiloh, M.U. Reactive oxygen and nitrogen intermediates in the relationship between mammalian hosts and microbial pathogens. Proc. Natl. Acad Sci. USA 2000, 97, 8841-8848. [CrossRef] 
97. Vander Heiden, M.G.; Cantley, L.C.; Thompson, C.B. Understanding the Warburg effect: The metabolic requirements of cell proliferation. Science 2009, 324, 1029-1033. [CrossRef]

98. Escoll, P.; Buchrieser, C. Metabolic reprogramming of host cells upon bacterial infection: Why shift to a Warburg-like metabolism? FEBS J. 2018, 285, 2146-2160. [CrossRef]

99. Hu, J.; Jin, K.; He, Z.G.; Zhang, H. Citrate lyase CitE in Mycobacterium tuberculosis contributes to mycobacterial survival under hypoxic conditions. PLOS ONE 2020, 15, e0230786. [CrossRef]

100. Dai, Z.L.; Li, X.L.; Xi, P.B.; Zhang, J.; Wu, G.; Zhu, W.Y. L-Glutamine regulates amino acid utilization by intestinal bacteria. Amino Acids 2013, 45, 501-512. [CrossRef]

101. Eisenreich, W.; Heesemann, J.; Rudel, T.; Goebel, W. Metabolic host responses to infection by intracellular bacterial pathogens. Front. Cell. Infect. Microbiol. 2013, 3, 24. [CrossRef] [PubMed]

102. Marrero, J.; Rhee, K.Y.; Schnappinger, D.; Pethe, K.; Ehrt, S. Gluconeogenic carbon flow of tricarboxylic acid cycle intermediates is critical for Mycobacterium tuberculosis to establish and maintain infection. Proc. Natl. Acad. Sci. USA 2010, 107, 9819-9824. [CrossRef] [PubMed]

103. Sanchez, E.L.; Lagunoff, M. Viral activation of cellular metabolism. Virology 2015, 479-480, 609-618. [CrossRef] [PubMed]

104. Izquierdo-Useros, N.; Naranjo-Gomez, M.; Erkizia, I.; Puertas, M.C.; Borras, F.E.; Blanco, J.; Martinez-Picado, J. HIV and mature dendritic cells: Trojan exosomes riding the Trojan horse? PLoS Pathog. 2010, 6, e1000740. [CrossRef] [PubMed]

105. Sitole, L.J.; Williams, A.A.; Meyer, D. Metabonomic analysis of HIV-infected biofluids. Mol. Biosyst. 2013, 9 , 18-28. [CrossRef]

106. Nakaya, H.I.; Pulendran, B. Vaccinology in the era of high-throughput biology. Philos. Trans. R. Soc. Lond. B Biol. Sci. 2015, 370. [CrossRef]

107. Nakaya, H.I.; Pulendran, B. Systems vaccinology: Its promise and challenge for HIV vaccine development. Curr. Opin. HIV AIDS 2012, 7, 24-31. [CrossRef]

108. Pulendran, B.; Li, S.; Nakaya, H.I. Systems Vaccinology. Immunity 2010, 33, 516-529. [CrossRef]

109. Borriello, F.; van Haren, S.D.; Levy, O. First International Precision Vaccines Conference: Multidisciplinary Approaches to Next-Generation Vaccines. Msphere 2018, 3. [CrossRef]

110. Hagan, T.; Cortese, M.; Rouphael, N.; Boudreau, C.; Linde, C.; Maddur, M.S.; Das, J.; Wang, H.; Guthmiller, J.; Zheng, N.Y.; et al. Antibiotics-Driven Gut Microbiome Perturbation Alters Immunity to Vaccines in Humans. Cell 2019, 178, 1313-1328 e1313. [CrossRef]

111. Khan, A.; Shin, O.S.; Na, J.; Kim, J.K.; Seong, R.K.; Park, M.S.; Noh, J.Y.; Song, J.Y.; Cheong, H.J.; Park, Y.H.; et al. A Systems Vaccinology Approach Reveals the Mechanisms of Immunogenic Responses to Hantavax Vaccination in Humans. Sci. Rep. 2019, 9, 4760. [CrossRef] [PubMed]

112. Dhur, A.; Galan, P.; Hercberg, S. Folate status and the immune system. Prog. Food Nutr. Sci. 1991, 15, 43-60. [PubMed]

113. Oh, K.Y.; Kang, M.J.; Choi, W.A.; Kwon, J.W.; Kim, B.J.; Yu, J.; Hong, S.J. Association Between Serum IgE Levels and the CTLA4 + 49A/G and FCER1B-654C/T Polymorphisms in Korean Children With Asthma. Allergy Asthma Immunol. Res. 2010, 2, 127-133. [CrossRef] [PubMed]

114. Manzetti, S.; Zhang, J.; van der Spoel, D. Thiamin function, metabolism, uptake, and transport. Biochemistry 2014, 53, 821-835. [CrossRef] [PubMed]

115. Sharma, V.; Chitranshi, N.; Agarwal, A.K. Significance and biological importance of pyrimidine in the microbial world. Int. J. Med. Chem. 2014, 2014, 202784. [CrossRef]

116. Ferreira, A.M.; Ferrari, M.I.; Trostchansky, A.; Batthyany, C.; Souza, J.M.; Alvarez, M.N.; Lopez, G.V.; Baker, P.R.; Schopfer, F.J.; O'Donnell, V.; et al. Macrophage activation induces formation of the anti-inflammatory lipid cholesteryl-nitrolinoleate. Biochem. J. 2009, 417, 223-234. [CrossRef] [PubMed]

117. Naito, T.; Irie, H.; Tsujimoto, K.; Ikeda, K.; Arakawa, T.; Koyama, A.H. Antiviral effect of arginine against herpes simplex virus type 1. Int. J. Mol. Med. 2009, 23, 495-499. [CrossRef]

118. Goll, J.B.; Li, S.; Edwards, J.L.; Bosinger, S.E.; Jensen, T.L.; Wang, Y.; Hooper, W.F.; Gelber, C.E.; Sanders, K.L.; Anderson, E.J.; et al. Transcriptomic and Metabolic Responses to a Live-Attenuated Francisella tularensis Vaccine. Vaccines 2020, 8, 412. [CrossRef]

119. Kuhtreiber, W.M.; Tran, L.; Kim, T.; Dybala, M.; Nguyen, B.; Plager, S.; Huang, D.; Janes, S.; Defusco, A.; Baum, D.; et al. Long-term reduction in hyperglycemia in advanced type 1 diabetes: The value of induced aerobic glycolysis with BCG vaccinations. NPJ Vaccines 2018, 3, 23. [CrossRef] 
120. McClenathan, B.M.; Stewart, D.A.; Spooner, C.E.; Pathmasiri, W.W.; Burgess, J.P.; McRitchie, S.L.; Choi, Y.S.; Sumner, S.C. Metabolites as biomarkers of adverse reactions following vaccination: A pilot study using nuclear magnetic resonance metabolomics. Vaccine 2017, 35, 1238-1245. [CrossRef]

121. McClenathan, B.M.; Edwards, K.M. Vaccine safety: An evolving evidence-based science. Br. J. Clin. Pharmacol. 2019, 85, 2649-2651. [CrossRef] [PubMed]

122. Arts, R.J.; Joosten, L.A.; Netea, M.G. Immunometabolic circuits in trained immunity. Semin. Immunol. 2016, 28, 425-430. [CrossRef]

123. Li, P.; Yin, Y.L.; Li, D.; Kim, S.W.; Wu, G. Amino acids and immune function. Br. J. Nutr. 2007, 98, $237-252$. [CrossRef] [PubMed]

124. Wu, G. Amino acids: Metabolism, functions, and nutrition. Amino Acids 2009, 37, 1-17. [CrossRef]

125. Ren, W.; Rajendran, R.; Zhao, Y.; Tan, B.; Wu, G.; Bazer, F.W.; Zhu, G.; Peng, Y.; Huang, X.; Deng, J.; et al. Amino Acids As Mediators of Metabolic Cross Talk between Host and Pathogen. Front. Immunol. 2018, 9, 319. [CrossRef]

126. Ren, W.; Duan, J.; Yin, J.; Liu, G.; Cao, Z.; Xiong, X.; Chen, S.; Li, T.; Yin, Y.; Hou, Y.; et al. Dietary L-glutamine supplementation modulates microbial community and activates innate immunity in the mouse intestine. Amino Acids 2014, 46, 2403-2413. [CrossRef] [PubMed]

127. Koeken, V.; Lachmandas, E.; Riza, A.; Matzaraki, V.; Li, Y.; Kumar, V.; Oosting, M.; Joosten, L.A.B.; Netea, M.G.; van Crevel, R. Role of Glutamine Metabolism in Host Defense Against Mycobacterium tuberculosis Infection. J. Infect. Dis. 2019, 219, 1662-1670. [CrossRef] [PubMed]

128. Karinch, A.M.; Pan, M.; Lin, C.M.; Strange, R.; Souba, W.W. Glutamine metabolism in sepsis and infection. J. Nutr. 2001, 131, 2535S-2538S; discussion 2550S-2551S. [CrossRef]

129. Ma, E.H.; Bantug, G.; Griss, T.; Condotta, S.; Johnson, R.M.; Samborska, B.; Mainolfi, N.; Suri, V.; Guak, H.; Balmer, M.L.; et al. Serine Is an Essential Metabolite for Effector T Cell Expansion. Cell Metab. 2017, 25, 345-357. [CrossRef]

130. Passalacqua, K.D.; Lu, J.; Goodfellow, I.; Kolawole, A.O.; Arche, J.R.; Maddox, R.J.; Carnahan, K.E.; O'Riordan, M.X.D.; Wobus, C.E. Glycolysis Is an Intrinsic Factor for Optimal Replication of a Norovirus. mBio 2019, 10. [CrossRef]

131. Hayek, I.; Fischer, F.; Schulze-Luehrmann, J.; Dettmer, K.; Sobotta, K.; Schatz, V.; Kohl, L.; Boden, K.; Lang, R.; Oefner, P.J.; et al. Limitation of TCA Cycle Intermediates Represents an Oxygen-Independent Nutritional Antibacterial Effector Mechanism of Macrophages. Cell Rep. 2019, 26, 3502-3510. [CrossRef] [PubMed]

132. Ulas, T.; Pirr, S.; Fehlhaber, B.; Bickes, M.S.; Loof, T.G.; Vogl, T.; Mellinger, L.; Heinemann, A.S.; Burgmann, J.; Schoning, J.; et al. S100-alarmin-induced innate immune programming protects newborn infants from sepsis. Nat. Immunol. 2017, 18, 622-632. [CrossRef]

133. Dreschers, S.; Ohl, K.; Lehrke, M.; Mollmann, J.; Denecke, B.; Costa, I.; Vogl, T.; Viemann, D.; Roth, J.; Orlikowsky, T.; et al. Impaired cellular energy metabolism in cord blood macrophages contributes to abortive response toward inflammatory threats. Nat. Commun. 2019, 10, 1685. [CrossRef] [PubMed]

134. Yin, J.; Ren, W.; Huang, X.; Deng, J.; Li, T.; Yin, Y. Potential Mechanisms Connecting Purine Metabolism and Cancer Therapy. Front. Immunol. 2018, 9, 1697. [CrossRef] [PubMed]

135. Yegutkin, G.G. Nucleotide-and nucleoside-converting ectoenzymes: Important modulators of purinergic signalling cascade. Biochim. Biophys. Acta 2008, 1783, 673-694. [CrossRef] [PubMed]

136. Rai, B.; Kaur, J.; Jacobs, R.; Anand, S.C. Adenosine deaminase in saliva as a diagnostic marker of squamous cell carcinoma of tongue. Clin. Oral Investig. 2011, 15, 347-349. [CrossRef]

137. Passos, D.F.; Bernardes, V.M.; da Silva, J.L.G.; Schetinger, M.R.C.; Leal, D.B.R. Adenosine signaling and adenosine deaminase regulation of immune responses: Impact on the immunopathogenesis of HIV infection. Purinergic Signal. 2018, 14, 309-320. [CrossRef]

138. Staley, C.; Weingarden, A.R.; Khoruts, A.; Sadowsky, M.J. Interaction of gut microbiota with bile acid metabolism and its influence on disease states. Appl. Microbiol. Biotechnol. 2017, 101, 47-64. [CrossRef]

139. Oh, J.Z.; Ravindran, R.; Chassaing, B.; Carvalho, F.A.; Maddur, M.S.; Bower, M.; Hakimpour, P.; Gill, K.P.; Nakaya, H.I.; Yarovinsky, F.; et al. TLR5-Mediated Sensing of Gut Microbiota Is Necessary for Antibody Responses to Seasonal Influenza Vaccination. Immunity 2014, 41, 478-492. [CrossRef]

140. Kloverpris, H.N.; Kazer, S.W.; Mjosberg, J.; Mabuka, J.M.; Wellmann, A.; Ndhlovu, Z.; Yadon, M.C.; Nhamoyebonde, S.; Muenchhoff, M.; Simoni, Y.; et al. Innate Lymphoid Cells Are Depleted Irreversibly during Acute HIV-1 Infection in the Absence of Viral Suppression. Immunity 2016, 44, 391-405. [CrossRef] 
141. Clish, C.B. Metabolomics: An emerging but powerful tool for precision medicine. Cold Spring Harb. Mol. Case Stud. 2015, 1, a000588. [CrossRef] [PubMed]

142. Tsugawa, H.; Satoh, A.; Uchino, H.; Cajka, T.; Arita, M.; Arita, M. Mass Spectrometry Data Repository Enhances Novel Metabolite Discoveries with Advances in Computational Metabolomics. Metabolites 2019, 9 , 119. [CrossRef] [PubMed]

143. Deelen, J.; Kettunen, J.; Fischer, K.; van der Spek, A.; Trompet, S.; Kastenmuller, G.; Boyd, A.; Zierer, J.; van den Akker, E.B.; Ala-Korpela, M.; et al. A metabolic profile of all-cause mortality risk identified in an observational study of 44,168 individuals. Nat. Commun. 2019, 10, 3346. [CrossRef] [PubMed]

144. Food and Drug Administration, HHS. Medical devices; clinical chemistry and clinical toxicology devices; classification of newborn screening test systems for amino acids, free carnitine, and acylcarnitines using tandem mass spectrometry. Final rule. Fed. Regist. 2004, 69, 68254-68255.

145. Patel, R. Maldi-tof ms for the diagnosis of infectious diseases. Clin. Chem. 2015, 61, 100-111. [CrossRef]

146. Herman, W.A.; Devey, G.B. Future Trends in Medical Device Technologies: A Ten-Year Forecast. Food Drug Adm. Cent. Devices Radiol. Health 2011.

147. Wilson, I.D. Metabolic phenotyping by liquid chromatography-mass spectrometry to study human health and disease. Anal. Chem. 2015, 87, 2519. [CrossRef]

148. Holmes, E.; Wilson, I.D.; Nicholson, J.K. Metabolic phenotyping in health and disease. Cell 2008, 134, 714-717. [CrossRef]

149. Fernandez-Garcia, M.; Rojo, D.; Rey-Stolle, F.; Garcia, A.; Barbas, C. Metabolomic-Based Methods in Diagnosis and Monitoring Infection Progression. Exp. Suppl. 2018, 109, 283-315. [CrossRef]

150. Zurfluh, S.; Baumgartner, T.; Meier, M.A.; Ottiger, M.; Voegeli, A.; Bernasconi, L.; Neyer, P.; Mueller, B.; Schuetz, P. The role of metabolomic markers for patients with infectious diseases: Implications for risk stratification and therapeutic modulation. Expert Rev. Anti Infect. Ther. 2018, 16, 133-142. [CrossRef]

151. Beger, R.D.; Schmidt, M.A.; Kaddurah-Daouk, R. Current Concepts in Pharmacometabolomics, Biomarker Discovery, and Precision Medicine. Metabolites 2020, 10, 129. [CrossRef] [PubMed]

152. Bhattacharya, S.; Andorf, S.; Gomes, L.; Dunn, P.; Schaefer, H.; Pontius, J.; Berger, P.; Desborough, V.; Smith, T.; Campbell, J.; et al. ImmPort: Disseminating data to the public for the future of immunology. Immunol. Res. 2014, 58, 234-239. [CrossRef] [PubMed]

153. Bhattacharya, S.; Dunn, P.; Thomas, C.G.; Smith, B.; Schaefer, H.; Chen, J.; Hu, Z.; Zalocusky, K.A.; Shankar, R.D.; Shen-Orr, S.S.; et al. ImmPort, toward repurposing of open access immunological assay data for translational and clinical research. Sci. Data 2018, 5, 180015. [CrossRef] [PubMed]

Publisher's Note: MDPI stays neutral with regard to jurisdictional claims in published maps and institutional affiliations.

(C) 2020 by the authors. Licensee MDPI, Basel, Switzerland. This article is an open access article distributed under the terms and conditions of the Creative Commons Attribution (CC BY) license (http://creativecommons.org/licenses/by/4.0/). 